International Journal of Engineering \& Technology, $7(4.20)(2018) 496-501$
Sinternational Journal of Engineering \& Technology
Website www.sciencepubco.com/index.php/IJET
Research paper

\title{
The Environmental Criteria as a Strategy to Adapt Climate Changes in Iraq
}

\author{
Susan Abed Hassan \\ Al- Nahrain University/ College of Engineering/ Architectural Department \\ *Corresponding author E-mail: dr.susanabedhassan@eng.nahrainuniv.edu.iq
}

\begin{abstract}
The Climate change appears obviously in the world, especially in hot climate regions like Iraq, because of their proximity to the equator and the geographical desert nature, which requires strategies to adapt climate change in effective ways. One of the most prominent of these strategies is the implemented of environmental criteria for buildings, to minimize the climate change effect. This research problem is that no obvious perception for the obstacles and the assistant methods for adopted environmental criteria as a strategy to adapt climate changes in Iraq". To solve this problem a questionnaire were designed about the main research indicators and delivered to the building industry practitioners. Statistical analysis were used to calculate the results, using IBM SPSS V23 software, the results find that the obstacles of application environmental criteria are economic, social, technical, and legislation. And the assistant method includes developing technical aspects, enabling human resources, cooperation with responsible authorities and decision-makers, and community awareness. The results indicated many recommendations for the local government, community organizations and the workers to implement environmental criteria as a strategy to adapted climate change in Iraq.
\end{abstract}

Keywords: Adaptation, Climate change, Environmental criteria, Legislation, Strategy

\section{Introduction}

The consumption of natural resources has increased significantly since the 20th century. The industry of building formed one of the main consumption of natural resources. In spite of the attempts a number of designers to take into account the environmental aspects in the designs and construction of buildings, but it have been individual attempts to improve the status of buildings industry and energy consumption. This was accompanied by the appearance of a number of climatic changes in all world countries, especially in the countries near the equator of the desert nature of high temperatures and lack of rainfall and fluctuation, and in order to guide the new generation of designers the importance of taking into account the environmental aspects in buildings and reduce the waste of energy and natural resources. The applications of environmental criteria have been limited and need the full support of local government and community organizations and educate the society. Ibrahim Abdel Gelil, Vice Dean [1] studied the challenges of the Arab countries as a result of climate change and reviewed the possibilities of threatening them and their resilience while studied the economic potentials in the Arab cities to achieve sustainable development. The most prominent of these obstacles in the building sector are economic problems, legal legislation and community awareness. A number of the strategies proposed were presented (general policy, energy investment promotion, renewable energy investment, adoption of appropriate legislation, study of carbon consumption in cities, development of future energy plans, promotion of scientific research on energy, community awareness, etc.). Global Status report 2017[2] this report showed the global need to rationalize energy consumption in the production of buildings and the responsibilities of the world, including the Paris Agreement
XI, which showed the increasing need to reduce emissions of pollutants from the building industry. The most prominent aspects are the sustainability of buildings, which include (development of environmental aspects in building, technological and technical development, enhancement of cities and smart buildings, economic promotion, public administration, preparation and adoption of environmental codes, promotion of environmental investment). Henk Visscher, Jacques Laubscher \& Edwin Chan [3] indicated the need to establish determinants and laws by government agencies that control energy consumption in buildings, taking into account the variables such as the location of the building, the pattern of use, and the urbanization of the cities. The index of measuring the electrical energy per square meter or the emissions of carbon dioxide per square meter used for cooling and heating, lighting, and water heating. Take into account the number of people using the space, the importance of community awareness of energy consumption and rationalization, energy-saving building materials. Marksnow and Deo Prasad [4] studied the impact of global climate change on the whole world, the weakness of the community awareness of its impact on buildings and cities, and the importance of environmental hazards and challenges being taken by engineers. (Climate change, hurricanes, floods, rain, extreme heat and cold, earthquakes, high water levels). [5] Studied the correlation between climate change and the urban environment within the four basic frameworks: social, policy, scientific, technological and economic issues. By studying community issues, appropriate environmental policies for communities and their local specificities can be developed. The awareness of climatic changes and their monitoring of high temperatures, carbon air pollution, water pollution and energy consumption by the scientific community help decision-makers to develop laws to achieve proper planning for the future. Technological innovation offers a variety of ways to adapt cities to climate change taking into account current 
and future economic issues. From the review of previous studies, it can be concluded that research problem is no obvious perception for the obstacles and the assistant methods for adopted environmental criteria as a strategy to adapt climate changes in Iraq", so the research hypotheses is that "the application of the environmental criteria for buildings needs to identify the obstacles and the assistant methods in order to adopted it as a strategy to adapt climate changes in Iraq ". The structure of the research contains the theoretical aspect of the research, a general definition of the concepts of the subject, up to the practical aspect, which included the applied procedures for research.

\subsection{Iraq climate and climate change}

Iraq's climate is divided into three main climatic zones based on precipitation: the desert zone to the west, the steppe in central and southern Iraq, and the Mediterranean climate region in northern Iraq. The desert zone is characterized by hot dry, average temperature in winter between $4^{\circ} \mathrm{C}$ to $17^{\circ} \mathrm{C}$, while in summer temperatures rise between $25-43^{\circ} \mathrm{C}$. There is also an extreme difference between temperatures between $-8^{\circ} \mathrm{C}$ in winter and $48^{\circ} \mathrm{C}$ in summer. Rain rates are almost non-existent in this zone. The steppe zone is characterized by high temperatures and higher rainfall than the desert zone. Temperatures in Baghdad are between 5 ${ }^{\circ} \mathrm{C}$ and $18^{\circ} \mathrm{C}$, while in the summer temperatures rise between 26 ${ }^{\circ} \mathrm{C}$ and $46^{\circ} \mathrm{C}$. Rain amounts are between $200-400 \mathrm{~mm}$ per year [6]. The mountainous zone is cooler and temperatures range from $27-44^{\circ} \mathrm{C}$, while rainfall in the winter is between $400 \mathrm{~mm}-1000$ $\mathrm{mm}$. Climate changes are evident in Iraq, with general temperatures rising from 1950 at an annual rate of 0.7 per decade. And is expected to continue rising to 2.2 degrees Celsius in $2050 \mathrm{com}$ pared to 1900, while rainfall fell in Baghdad by 25 percent compared to previous rates for the same period of time. [7].

\subsection{The climatic change effects on buildings and cities}

Climate changes in the world effects on buildings and cities in many aspects particularly in hot climate countries [8]. Summarized of the negative effects of climate change on buildings are on the following table:

Table 1: The negative effects of climate change on buildings (8)

\begin{tabular}{c|c}
\multicolumn{2}{c}{ Table 1: The negative effects of climate change on buildings (8) } \\
\hline $\begin{array}{c}\text { Climate } \\
\text { change fac- } \\
\text { tors }\end{array}$ & The negative effects \\
\hline $\begin{array}{c}\text { Temperatures } \\
\text { Water }\end{array}$ & $\begin{array}{c}\text { - Increased cooling loads (and cooling costs) } \\
\text { - Building envelope (roofing, cladding, window systems) } \\
\text { at increased risk of cracking/ failure. Sealants and finish- } \\
\text { es are also potentially affected }\end{array}$ \\
$\begin{array}{c}\text { Radiation } \\
\text { Dust storms }\end{array}$ & $\begin{array}{r}\text { - soil drying and movement (could affect foundations, } \\
\text { especially clay soils) }\end{array}$ \\
$\begin{array}{c}\text { Relative } \\
\text { humidity }\end{array}$ & $\begin{array}{c}\text { - Because of the lack of fresh water in the world with the } \\
\text { Increasing of temperatures, it is necessary to reduce the } \\
\text { consumption of water inside buildings by the efficient } \\
\text { design of water pipes and accessories. }\end{array}$ \\
\hline
\end{tabular}

\section{Strategies for adaptation to climate change}

\subsection{Strategies}

The Oxford dictionary defined Strategy as the Action Plan for Achieving a Long-Term Goal.[9] It has also been defined as a general plan or set of plans aimed at achieve a goal, specifically in the long term. [10] It is also known as the science and art of employing the political, economic, psychological and military energies of a particular people or group of peoples to support certain goals in peace and war [11]. The previous definitions show that the strategy represents a plan of action or a set of plans studied by specific organization to reach the goals of a long-period and em- ploy all political, economic, psychological, military and other to achieve them.

\subsection{Legislation}

A number of strategies have been adopted globally to address global climate change. Among these strategies are the performing of legislations, with the increasing in it to reach in 2017 to 1,200 in 164 countries compared with 1997 by 60 laws, which shows the increasing importance of climate laws and legislation. [12] In Iraq, the United Nations Framework Convention on Climate Change (UNFCCC) issued a number of project packages that could be implemented according to the mitigation scenario for different sectors such as industry, transport, agriculture, housing and others. For housing sector many scenario were Endorsement, in the first conditional scenario (Use energy-saving techniques) throw:

- Use thermal insulation techniques

- Improve green building criteria

- Use effective design of buildings to make the most of lighting and solar energy.

Within the second conditional scenario

- Implementation of photovoltaic electricity technologies distributed to small regions and cities

- Integrated design includes the use of smart meters technology inside buildings

- Solar PV integrated in buildings

- Promote the production and use of building materials and environmentally friendly domestic products.

\subsection{Adaptation}

Adaptation has been defined as "modification of natural or human systems in response to actual or expected climate effects (fluctuations, extreme events, changes) and their effects, or take advantage of opportunities ". Natural phenomena such as floods, earthquakes, volcanoes, high water levels, extremes of temperature and rain are the most prominent of what man has encountered and worked to minimize its effects. Adaptation to climate change is a considered model of environmental risk management according to a number of steps: [13]

1.Context identification (study of the context of natural, geographical and environmental aspects and the extent of climate changes and their effects, whether small, medium or large)

2. Analysis of climate changes (development of detailed climate studies, study of climate changes throughout history)

3. Assessment of climate change (development of agendas that reflect future climate change and ranges of change)

4.Developing strategies for climate adaptation (addressing environmental risks such as floods and extreme temperatures through legislation, laws and standards for implementation)

5.Implementation and control (implementation of laws, legislation and standards in various sectors, including construction)

\subsection{Environmental criteria}

Environmental criteria are designed to simulate expected models that can be adopted by reducing the negative effects on the human environment. Environmental criteria are adopted as technical systems accordance their ability to protect consumers, employees and employers, while at the same time preserving natural ecosystems. [14] Environmental criteria consist of a number of determinants designed to suit local environmental for each country. Although there are a number of constants among them which can thus be summarized:-

A- Energy efficiency and renewable energy

- Directing the building to obtain the best shading and avoid sun exposure in summer, and better exposure and enter the sun in winter, and the best natural lighting for all seasons.

- Building a mini-climate for the building and taking advantage of its positives.

- Thermal efficiency of building envelop and openings. 
- A system of air conditioning, ventilation, and heating efficient and suitable size.

- An efficient design that minimizes electrical loads for lighting, devices and equipment to the minimum possible.

- Service incentives to support and budget costs, to encourage adoption of renewable energy options of all types, especially solar and wind. [15]

B. Quality of the internal environment

-Control the volatile organic components of building materials.

-Prevent (or minimize) bacterial growth opportunities.

- Proper processing ratio for pure external air.

-Control and control of chemical content and volatility of maintenance and cleaning materials.

-Control and (minimize) the sources of internal pollution of the work equipment and personal equipment of the occupants.

- Sound control is appropriate and efficient.

- Provides daytime lighting and a psychologically comfortable look on the outside. [15]

C. Rationalize, conserve and recycle resources

-Use recyclable products and those containing recyclable materials.

- Re-use the building components, equipment and furniture as much as possible.

-Minimizing waste and debris when reused or recycled.

- Preserving water and rationalizing its consumption in the works of building and watering plantations and gardens.

-Reduction of water waste through the recycling and use of gray water.

-Providing different alternatives to water treatment methods.

-Enable the occupants of the building to benefit easily from the means of recycling. [14]

D. Direct and indirect environmental impacts

-Maintaining the integrity of the site, cover or vegetation, and water resources.

- Minimize non-point-source sources of pollution.

- The impact of materials selection on depletion of resources and pollution of air and water.

- Use of materials produced or obtained from sustainable sources, such as materials produced from recycling and timber from sustainably managed forests.

- The use of local plants and a small need for irrigation, in the plant works of the site.

- Integrated management of pests and insects. [15]

E. Community issues

- Promoting access to the site by public transport, pedestrian and bicycle routes.

- Attention to the culture and history of society.

- Develop local incentives, define policies and enact legislation to promote and encourage adoption of green design.

- Establishing a physical and social infrastructure for the recycling of rubble, construction waste and others.

- Local availability of environmental products and expertise.

From the above, the study of environmental criteria for buildings shows the importance of being committed to adapting to climate change, as these criteria contribute to reducing the consumption of natural resources, reducing energy consumption, reducing pollution and water drainage, which enables people in hot areas to adapted with climate change. [15]

\section{Research Methodology}

The research implemented procedure to achieve the objectives of the research from selection of research sample and description and then the method of data collection and analysis.

1 - Samples: By identifying the most prominent indicators and concentrations to provide proposals as the following:

- The stockholders in the building process for the adoption and implementation of environmental criteria were selected to provide views on obstacles and assistant methods to adopt environmental criteria.
- Selection of the research community (employers, engineers, academic institutions in engineering departments).

2 - Method of collecting information: - Information was obtained through the design of a questionnaire, the respondents were asked to evaluate the main obstacles to the adoption of environmental criteria in buildings and the assistant methods to adopt environmental criteria with range of evaluate ( 2 for agree, 1 for neutral, 0 for not agree) Then data processed and analysis to reach the results.

3 - Analysis of the results: - The results was analysis by use the IBM SPSS V23 software with descriptive statistics of the distributed form, a number of results in the main axes covered by the questionnaire and as shown in Annex (1)

\subsection{Results of the questionnaire}

\subsubsection{Obstacles to the adoption of environmental criteria}

The results of the questionnaire showed the main obstacles facing the adoption of environmental criteria to adapt to climate change. Economic, social, technical, and legislation. The result showed in Fig.1.

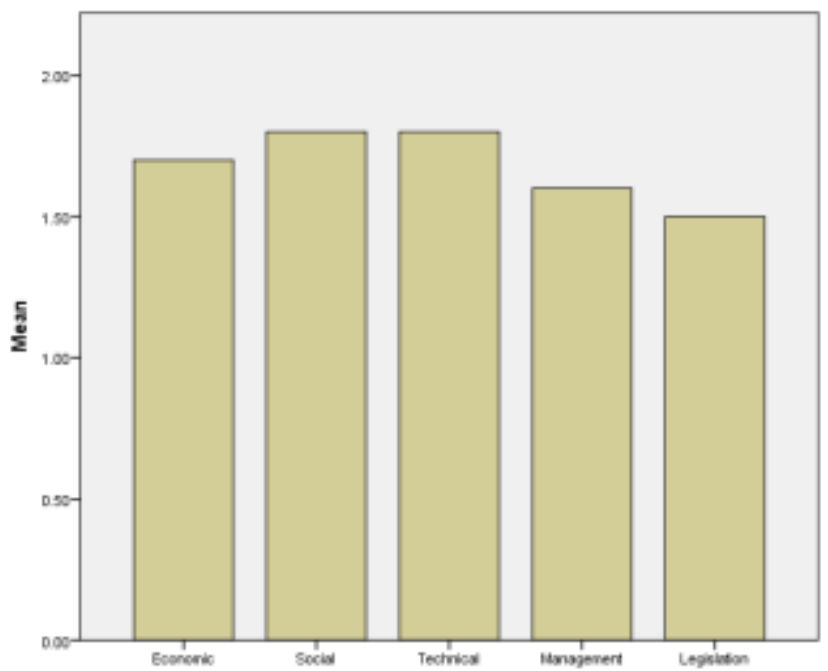

Fig. 1: Obstacles to the adoption of environmental criteria

As shown from Table 2, respondents reported that there is an agreement about the main obstacles facing the adoption of environmental criteria to adapt to climate change and that the most prominent obstacles according to the analysis are the social and technical obstacles

Table 2: Descriptive Statistics for the Obstacles to the adoption of environmental criteria

\begin{tabular}{c|c|c|c|c|c}
\hline & $\mathrm{N}$ & Minimum & Maximum & Mean & $\begin{array}{c}\text { Std. } \\
\text { Deviation }\end{array}$ \\
\hline Economic & 10 & .00 & 2.00 & 1.7000 & .67495 \\
Social & 10 & .00 & 2.00 & 1.8000 & .63246 \\
Technical & 10 & .00 & 2.00 & 1.8000 & .63246 \\
Management & 10 & .00 & 2.00 & 1.6000 & .84327 \\
Legislation & 10 & .00 & 2.00 & 1.5000 & .84984 \\
\hline
\end{tabular}

A- Economic obstacles

The results showed the effect of financial cost for projects that are designed and implemented on environmental criteria with the lack of financing procedure, as well as the incorrect conviction that investment in such projects represents a financial risk, although it reduces energy costs. And some banks and sources of financing may not encourage loans and investments in emerging areas as compared to conventional projects. This is supported by the fact that these investments may not be of a clear in-kind value and may not be economically attractive if compared to other investment opportunities.

B - Social obstacles 
The results showed the lack of attention to environmental aspects and climate change and misunderstanding by the peoples concerned and the society as a whole constitute a major obstacle to the adoption of environmental criteria. This impediment strengthens the general feeling among institutions and individuals of the lack of usefulness of environmental endeavors on the one hand and the feasibility of using environmental designs on the other, And the role of media and awareness to push towards the rehabilitation of individuals and communities as a whole towards the correct concept, taking into account not only awareness of information campaigns to the public, but should be extended to the repetition of training and technical education through training programs, Scientific workshops, conferences for engineers, technicians and even decision makers in various fields, which helps to clarify the economic, environmental and technical facts.

C. Technical obstacles

The results showed highly agreement of the lack of materials and construction techniques compatible to environmental criteria, lake of trained workers on environmental aspects and their applications in buildings, no specialized training in environmental criteria, and long implementation time for environmental criteria.

D. management obstacles

The results showed an agreement for the mismanagement and guidance of environmental criteria, and the lack of investment in the application of environmental criteria

E- Legislation obstacles

The results showed an agreement for the lack and a weakness of clear environmental criteria.

F-Other obstacles

The responses differed in this regard, ranging from the weakness of the regulatory bodies and the institutions responsible for the implementation of legislation and its association with the general economic aspect and lack of awareness of the importance of environmental aspects in buildings and other indicators.

\subsubsection{Methods for the adoption of environmental criteria}

The results of the questionnaire showed the existence of a number of methods that enabled the adoption of environmental criteria, which were as follows and showed in Figure.2.

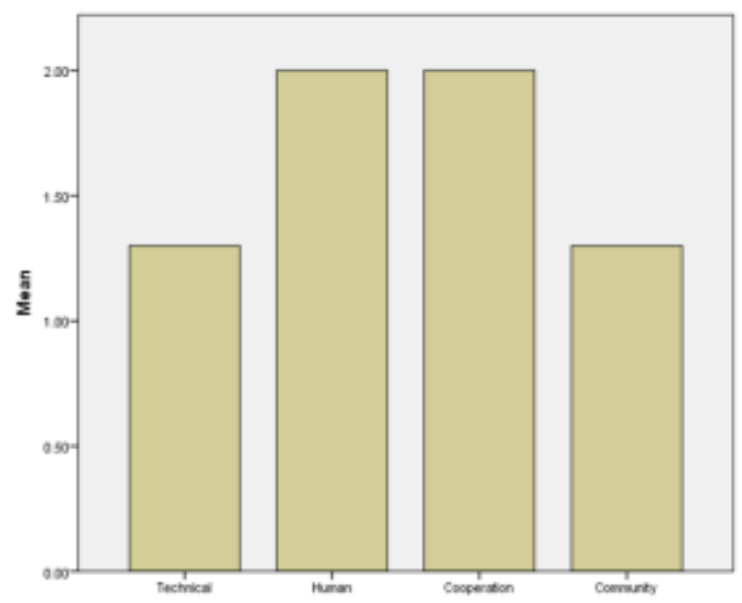

Fig. 2: Methods for the adoption of environmental criteria

As shown from Table 3, respondents reported that there is an agreement about the methods that enabled the adoption of environmental criteria especially in enabling human resources and cooperation with responsible authorities and decision-makers.

Table 3: Descriptive Statistics for the Methods for the adoption of environmental criteria

\begin{tabular}{c|c|c|c|c|c}
\hline & $\mathrm{N}$ & Minimum & Maximum & Mean & $\begin{array}{c}\text { Std. } \\
\text { Deviation }\end{array}$ \\
\hline $\begin{array}{c}\text { Developing } \\
\text { technical } \\
\text { aspects }\end{array}$ & 10 & .00 & 2.00 & 1.3000 & .94868 \\
$\begin{array}{c}\text { Enabling } \\
\text { human re- }\end{array}$ & 10 & 2.00 & 2.00 & 2.0000 & .00000 \\
\hline
\end{tabular}

\begin{tabular}{cccccc}
\hline $\begin{array}{c}\text { sources } \\
\text { Cooperation } \\
\text { with respon- } \\
\text { sible }\end{array}$ & 10 & 2.00 & 2.00 & 2.0000 & .00000 \\
$\begin{array}{c}\text { Community } \\
\text { awareness }\end{array}$ & 10 & .00 & 2.00 & 1.3000 & .82327 \\
\hline
\end{tabular}

A-Developing technical aspects

The results showed the important of considering develops of the technology process in construction. That promoting minimizes energy and water consumption, reduces air pollution at the level of building materials and structures, and the way of manufacturing buildings.

B- Enabling human resources

The results showed the importance of involving human resources of specialists in the field of construction in the process of analyzing the environmental effects resulting from the unintended consumption of energy sources in the construction of buildings and construction processes contaminated with water and air, and in the design of the strategy of developing environmental criteria in buildings and the development of environmental policies and in determining the plans of action for the development of performance In buildings. With the identification of the skills and capabilities needed to implement the strategy and initiatives. Develop training plans that ensure human resources to have the knowledge, necessary skills and behaviors to ensure the effective application of environmental criteria.

C- Cooperation with responsible authorities and decision-makers The results showed the role of the responsible organizations and the decision makers (including the ministries of housing, the environment, the municipal authorities, the Ministry of Finance (customs, taxation), scientific research, specifications and standards) in achieving and regulating the adoption of environmental criteria. It also includes many aspects in practical aspects such as permitting the fundamental approvals for building designs, On the construction of buildings, so it is important to cooperate with them in the development of environmental criteria and the work of analysis to demonstrate the efficiency and results of their applications on the ground, with plans to develop and activate them to adapt to climate change.

D- Community awareness

The results showed the lack of agreement on the importance of holding training courses, conferences, seminars and workshops within effective community centers and not only traditional centers (universities and engineering colleges) to include places dealing with wider social norms such as preparatory schools, institutes and recreational activities for the community, and Less agreement of the ethical motives effects, and an agreement to ensure that awareness-raising is not limited to media campaigns only for the public, but also decision-makers, which helps to clarify the economic, environmental and technical aspects

\section{Conclusions and Recommendations}

\subsection{Conclusions}

1. Environmental criteria are one of the most important strategies for adaptation to climate change in the world and in Iraq.

2. The need for clear plans and methods for the adoption of environmental criteria by the workers in the building field to overcome the obstacles that face them.

3. The importance of activating the adoption of environmental criteria in buildings and follow-up implementation by the legislators and standards in Iraq.

4. The need to activate the supply of building materials and techniques in Iraq that are appropriate to environmental criteria in buildings and contribute to adaptation to climate change.

5. The importance of establishing scientific courses on climate change and adaptation strategies, including environmental criteria and strengthening the views of specialists and experts with periodic review to develop and upgrade them. 
6. Lack of cooperation by the engineering organizations and experts with the competent government organizations in the legislation of environmental laws and criteria in Iraq.

7. Lack of a clear scientific plan for seminars and conferences on environmental criteria in buildings, and the need to increase media awareness. That includes all workers and decision-makers to participate and broader community base in events.

\subsection{Recommendations}

1. Develop strategic plans by the responsible specialists to encourage the adoption of environmental criteria in Iraq by specialists in the field of construction engineers, implementers and government organizations. With the importance of adopting them in the form of necessary laws or encouraging them with economic encouragements for the owners of buildings and flow them to be included in the curriculum of the specialized engineering colleges.

2. Activate the role of the responsible workers of the government and civil society organizations in the authorization of human resources to provide scientific courses on environmental criteria and strengthen the views of specialists and experts with periodic review in order to develop and improve them.

3 . The importance of the existence of cooperation between building organizations with the competent government organizations in Iraq as they have a decision in the legislation and encouragement of the laws, which necessitates the opening of channels of communication with them and the formation of specialized committees to cooperate with decision-makers in government organizations such as (Municipality of the capital and municipal consultants and quality control and others)

4. Determine a clear scientific plan for seminars and conferences on environmental criteria in buildings. Expand media awareness to include all workers and decision-makers to participate in cultural events. And possibility of expanding it to include a broader community base in Iraq.

\section{References}

[1] Ibrahim Abdel Gelil, Vice Dean . "Arab Climate Resilience Initiative Climate Change: Economic challenges and Opportunities in the
Arab Regions". United Nations Development Programme Regional Bureau for Arab States. http://www.arabclimateinitiative.org/Countries/bahrain/Abdel gelil _report_bahrain_mtg_with_cover_FINAL.pdf

[2] Global Status report,(2017)."Towards a zero-emission, efficient, and resilient buildings and construction sector". United Nations Environment Programme. United Nations Environment Programme. http://www.worldgbc.org

[3] Henk Visscher, Jacques Laubscher \& Edwin Chan,(2016) ."Building governance and climate change: roles for regulation and related polices". BUILDING RESEARCH \& INFORMATION, Vol. 44, Nos. 5-6, 461-467,

[4] Marksnow and Deo Prasad, (2011). .Climate changes Adaptation for building Designers: An Introduction". Australian Institute of Architects. Australia.

[5] Work shop report, (2009). "The Australian academy of technological Sciences and engineering". https://www.atse.org.au/atse/publications/annual-reports

[6] Iraqi Meteorological Organization \& Seismology Web site, http://www.meteoseism.gov.iq

[7] Evidence of Climate Change in Iraq Journal of Environment Protection and Sustainable Development.(2015), Vol. 1, No. 2, pp. 66 $73 \mathrm{http}: / /$ www.aiscience.org/journal/jepsd

[8] Ibid, 5.p2-9

[9] https://en.oxforddictionaries.com/definition/strategy $23 / 5$

[10] https://www.collinsdictionary.com/dictionary/english/strategy

[11] https://www.merriam-webster.com/dictionary/strategy

[12] Michal Nachmany, Sam Fankhauser, Joana Setzer and Alina Averchenkova, (2017)."Global trends in climate change legislation and litigation". Grantham Research Institute on Climate Change, The Environment at the London School of Economics and Political Science. https://www.ipu.org/resources/publications/reports.

[13] The Intergovernmental Panel on Climate Change (IPCC), (2011).

[14] http://www.ipcc.ch/scripts/_session_template.php?page=_34ipcc.ht

[15] Afify, Mohamed M. (2003)." Contemporary Trends in Environmental Design". Cairo.

[16] Green Building Rating System LEED V9, (2014). "Green Building Rating System for New Construction".

\section{ANNEX No. (1)}

Design the questionnaire form

Dear respondent ................ honored

We put in your hands the questionnaire prepared to complete the requirements of our research, which is related to "The environmental criteria as a strategy to adapt climate changes" This research is expected to contribute to identifying the most important obstacles and assistant methods in adopting environmental criteria, Please help to answer the paragraphs of the form accurately and objectively and we guarantee the complete personal confidentiality of the answers, although the form that did not answer all the paragraphs will be invalid for statistical analysis.

With a great appreciation and respect

\section{Part One}

First: Personal data

1- Name: ------------

2- Age:---------

3- Sex:----------

4- Professional rank (consultant, license, practitioner, other / remember):---

\section{Part Two: Study Variables}

Please mark in the appropriate box for the fallowing's two tables.

Table 1: the obstacles of adopting environmental criteria

\begin{tabular}{ll}
\hline The Variable & The secondary Indicators \\
\cline { 2 - 2 } 1. Economic & 1.1 Lack of economic motivations \\
\cline { 2 - 2 } & 1.2 Increase construction costs \\
\hline $\begin{array}{l}1.3 \text { Lack of investment appliance for environmental } \\
\text { projects }\end{array}$ \\
\hline 1.4 Lack of economic achievability \\
\hline
\end{tabular}




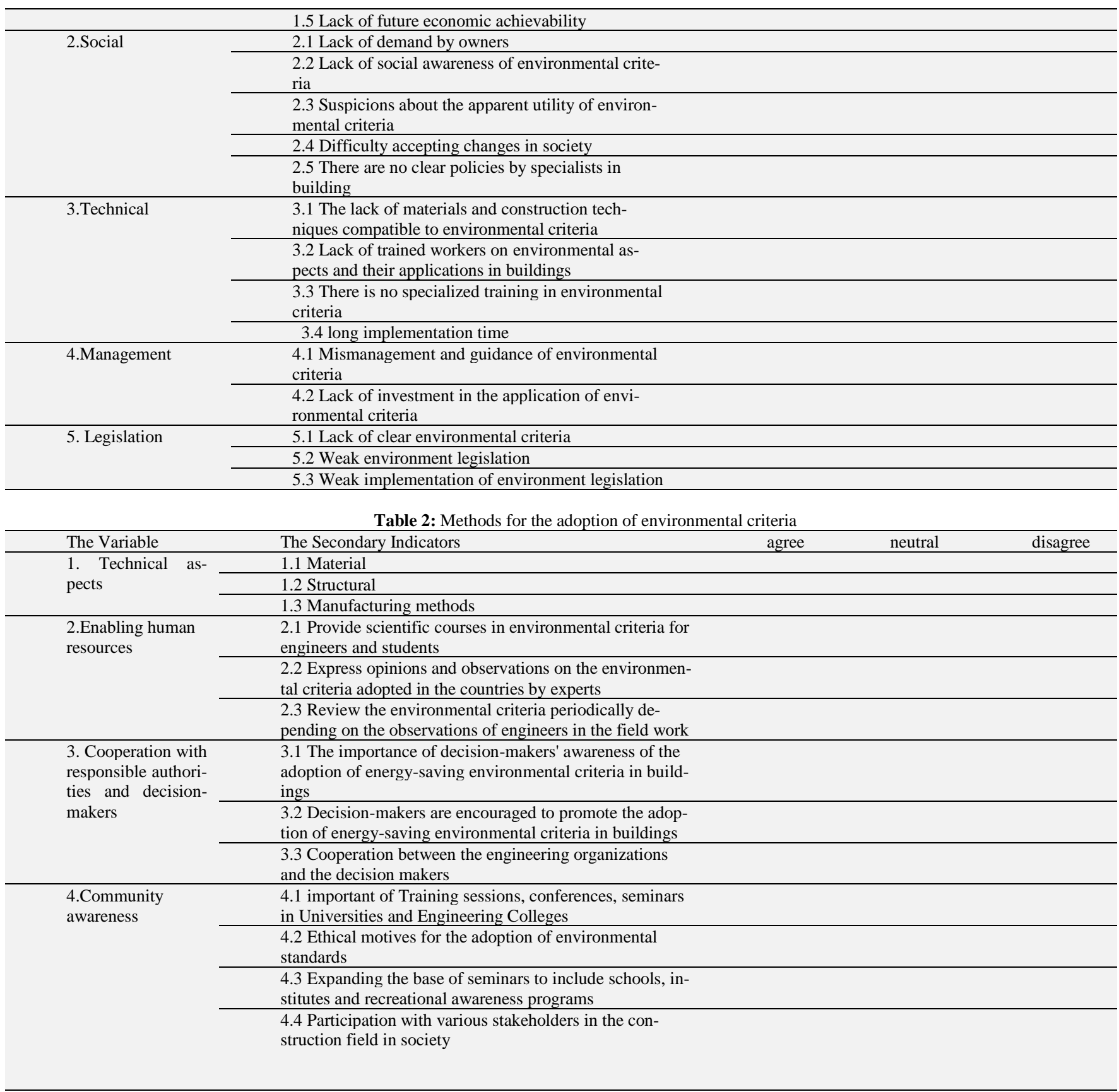

